\title{
CONSUMERS ATTITUDES ON ORGANIC FOOD IN SERBIA AND CROATIA: A COMPARATIVE ANALYSIS
}

\author{
Nenad Perić1, Andrijana Vasić Nikčevič², Nenad Vujič ${ }^{3}$
}

\begin{abstract}
Summary
The aim of this study was to investigate the association between socio-demographic variable and attitudes of respondents from Serbia and Croatia towards organic food. Consumers around the world have a positive attitude towards organic food without particular differences between various socio-demographic variables. However, the level of organic food consumption is low-organic farming covers $1 \%$ of agricultural land. High price and low income of respondents represent the basic limiting factors. The economic factor is especially important for the markets of Serbia and Croatia. Also, a lack of information and trust in the organic production and organic certificates constitute part of the decision in purchase. Therefore, manufactures of organic products needs marketing activities to build a recognizable brand and develop trust among consumers. Also, consumers have shown a high degree of self-awareness in making decisions about the purchase of organic products, which makes brand communication at the point of sale very important.
\end{abstract}

Key words: organic food consumption, consumer's attitude, decision making process

JEL: $Q 13, M 31$

\section{Introduction}

The concept of organic agriculture can be defined as "an ecological production management system that promotes and enhances biodiversity, biological cycles, and soil biological activity" (Cooley, R. et al, 2012). In other word, in organic agriculture there is an absence of any kind of non-natural growth regulators such as pesticides, genetically modified organism or conventional chemical inputs. Other authors believe that concept of organic agriculture should be define through its goals. Golijanin states that primary concern of organic agriculture is sustainable production of healthy and

1 Nenad Perić Ph.D., Associate Professor, Metropolitan University, Tadeuša Košćuška Street no. 63, 11000 Belgrade, Serbia, Phone: +381 112030 885, E-mail: nenad.peric@metropolitan.ac.rs

2 Andrijana Vasić-Nikčević M.Sc., Assistant, Metropolitan University, Tadeuša Košćuška Street No. 63, 11000 Belgrade, Serbia, Phone: +381 112030 885, E-mail: andrijana.vasic@metropolitan.ac.rs

3 Nenad Vujić Ph.D., Science Fellow, Economics Institute, Kralja Milana Street no. 16 Belgrade, Serbia, Phone: +381 113613 417, E-mail: nenadvujicvuja@,open.telekom.rs

EP 2017 (64) 3 (1049-1064) 
safe food and products (Golijanin, 2016), while Mirecki et al believes that purpose of organic agriculture is to create the natural system that enhance ecological balance and integrates the part od the farming into one ecological whole (Mirecki et al, 2011).

The idea of organic agriculture and food started to grow as the answer on capitalintensive agriculture which main aim is to produce more. Over exploitation of resources and usage of hazardous substance in production process created the negative influence on conventional food production (Ilić, 2016) As of 2001, the estimated market value of certified organic products was estimated to be $\$ 20$ billion. By 2012 the market had reached $\$ 63$ billion worldwide. (Willer, Lernoud, Home, 2013).

The report of the Institute of Organic Agriculture showed that more than 43.1 millions hectares in 147 researched countries is covered with organic farming and agriculture. This area is very low since it represents only $1 \%$ of total agriculture land globally (Willer, Lernoud, 2015).

The same institute reported that Australia, United States of America and Argentina are the countries with the largest organic farmland in the World (Willer, Lernoud, 2015). With value of 38.7 billions euros United States of America represent the most important market regarding the organic consumption while the Europe holds the second position with 26 billions euros. With 30\% of total sales share, Germany is the leading European country followed by France (18\%), United Kingdom (9\%) and Italy (8\%) (Heinze, 2016).

Chart 1. Europe: Retail sales 2014.

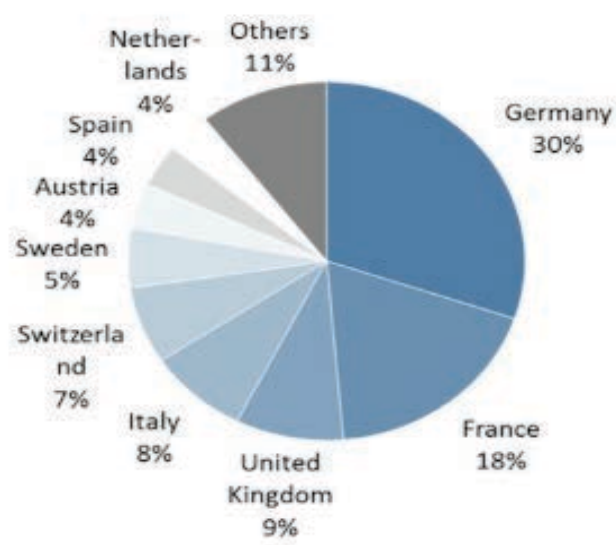

Chart 2. World: Retails sales 2014.

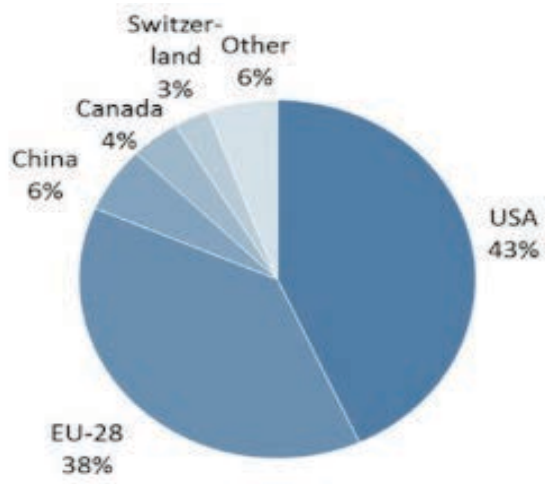

Source: Heinze, 2016.

It can be notice that countries, which are meter of this research, are not on this list.

These result are not corresponding with the amount of organic producers worldwide. The Institute of Organic Agriculture registered 2.4 millions organic producers where most of the registered producers are coming form Asia with 36\% of total area, following by Africa 29\%, Asia 26, Europe 17\% and Latin America 16\%. According to this result it can be 
concluded that almost $80 \%$ of organic producers are coming from developing countries and emerging markets (Wiler, Lernoud, 2017). Furthermore, in 1999, when this institute started to measure the organic agriculture development, there were only 200.000 organic producers. One of the reasons might be explained through the number of unemployment people in developing countries who see the organic farming as the good opportunity for business development. This paper will also reveal the attitude of the people in Croatia and Serbia about Organic farming potentials.

\section{Organic Market in Serbia and Croatia - Purchase Intention}

Total amount of organic agricultural land in Serbia in 2016 was proximally 15,298.02 hectares, which represents the $0.44 \%$ of total agriculture land (Simić, 2016). Even though these figures are very low they represent significant growth if we compere this result with research conducted by in 2014 (Willer, Lernound, 2014). According to their results total amount of organic agriculture in Serbia was 9,548 hectares while the value of the organic retail market was nearly 35 millions euros. Compering with the figures in Croatia where 76,000 hectares of land is covered with organic agriculture, organic market in Serbia is still on the beginning (Willer, Lernoud, 2015). Indeed, Table 1. and Table 2. showed that Serbian market is undeveloped compering with the both European and Regional organic markets. However the rise of the organic farming and producers in last decade is noteworthy with 1,281 organic producers (Willer, Lernoud, 2014). The market's growth of organic food is limited due to insufficient production and offer, so that there is significant market potential (Mitić, Gligorijević, 2012).

Table 1. A comparative overview of the indicators of organic food market development in Serbia and in select developed countries 2014.

\begin{tabular}{|l|l|l|l|l|l|}
\hline Country & Area (ha) & $\begin{array}{l}\text { Share of all } \\
\text { agr. land (\%) }\end{array}$ & $\begin{array}{l}\text { Producers } \\
(\text { no.) }\end{array}$ & $\begin{array}{l}\text { Retail sales } \\
(\text { million } €)\end{array}$ & €/person \\
\hline Serbia & 9,548 & 0.2 & 1,281 & $35(2012)$ & $4.4(2012)$ \\
\hline Austria & 525,521 & 19.4 & 22,184 & 1,065 & 127 \\
\hline Denmark & 165,773 & 6.3 & 2,565 & 912 & 162 \\
\hline Germany & $1.047,633$ & 6.3 & 23,398 & 7,910 & 97 \\
\hline Italy & $1.387,913$ & 10.8 & 48,662 & 2,145 & 35 \\
\hline France & $1,118,845$ & 4.1 & 26,466 & 4,830 & 73 \\
\hline $\begin{array}{l}\text { United } \\
\text { Kingdom }\end{array}$ & 521,475 & 3 & 3,526 & 2,307 & 36 \\
\hline Sweden & 501,831 & 16.4 & 5,406 & 1,402 & 145 \\
\hline Netherlands & 49,159 & 2.5 & 1,706 & 965 & 57 \\
\hline
\end{tabular}

Source: Willer, Lernoud, 2014, 2016. 
Table 2. A comparative overview of the indicators of organic food market development in Serbia and countries in the Region 2014.

\begin{tabular}{|l|l|l|l|l|l|}
\hline Country & Area (ha) & $\begin{array}{l}\text { Share of all } \\
\text { agr. land (\%) }\end{array}$ & $\begin{array}{l}\text { P r o d u c e r s } \\
(\text { no.) }\end{array}$ & $\begin{array}{l}\text { Retail sales } \\
\text { (million €) }\end{array}$ & €/person \\
\hline Serbia & 9,548 & 0,2 & 1.281 & $35(2012)$ & $4.4(2012)$ \\
\hline Romania & 289,252 & 2.1 & 14,159 & 80 & 4 \\
\hline Croatia & 50,054 & 3.8 & 2,194 & 99 & 23 \\
\hline Hungary & 124,841 & 2.7 & 1,672 & 25 & 2 \\
\hline Bulgaria & 74,351 & 2.4 & 3,893 & 7 & 1 \\
\hline Montenegro & 3,289 & 0.6 & 167 & 0 & 0 \\
\hline $\begin{array}{l}\text { Bosnia and } \\
\text { Herzegovina }\end{array}$ & 353 & 0.02 & 24 & 2 & 0 \\
\hline Macedonia & 3,146 & 0.3 & 382 & - & - \\
\hline Albania & 515 & 0.04 & 39 & - & - \\
\hline
\end{tabular}

Source: Willer, Lernoud, 2014, 2016.

In Table 2. we can also see the average value of organic product consumption per capita in both countries. With 4.4 euros per capita organic consumption in Serbia is very low compering with Croatia. Many authors, (Vlahović et al., 2011; Kalentić et al, 2014; Vehapiju, 2015) believes that reasons for low level of consumption are following: low average income, undeveloped distribution, lack of product variety, inappropriate labeled products and low level of information about importance of organic production among consumers. Truly, the low income tent to be the reason number one for low consumption especially if we compare the average income in Serbia with average income in Croatia; 405 euros and 790 euros respectively. Moreover, Vehapi reveals that $80.9 \%$ of consumers in Serbia is willing to pay a $30 \%$ higher price for organic food while the only $5.7 \%$ of them is willing to pay $100 \%$ higher price (Vehapi, 2015). This finding indicates high price elasticity on Serbian market. Similarly, the research conducted in Croatia shows that $61 \%$ of examinee describes price as important or most important purchase indicator while $70.0 \%$ of the respondents stated they would purchase more organic food if its price were lower (Stipčević, et al, 2011). However, many researches in both countries pointed out that mistrust in concept of organic food represent the main reason for low level of consumption (Zakowska-Biemans, 2011; Vlahović et al, 2011). Vehapi research shows that almost $38 \%$ of examinee doubt in the concept of organic food consumption (Vehapi, 2015). The research conducted in Croatia showed that consumers equalize organically grown food with traditionally grown food or "healthy" food (Stipčević, et al, 2011). Similarly, Roitner-Schobesberger et al found that many supermarkets on their shelves do not make a clear differentiation between health food and organic food (RoitnerSchobesberger et al 2008). That is why consumers do not make difference between terms such as: "safe food", "healthy food", "pesticide free", "chemical free" and "high quality food". As the result, they consider healthy food and organic food as synonyms (Lockie, 2006; Gifford, Bernard, 2011). These data point to the importance of informing about organic food. Lack of knowledge about the concept of organic farming and its benefits affect the level of trust. Additionally, same author believes that distrust of consumers in organic products is 
associated with their skepticism about certification authorities and organic regulations. Aerset et al. indicate that the lack of confidence in the organic production certificate is present in many countries and has significant negative effects on demand in the purchase of organic products (Aerset et al. 2004).

The rest of this paper will present results that indicate the importance of the media on consumer's attitudes toward organic consumption.

\section{The Aim of Research}

As it was mentioned in the beginning of this article the main aim of this research is to identify the differences among Serbian and Croatian consumers towards organic food consumption. The research investigated the association between socio-demographic variables such as gender, age, employment status, level of education and monthly income. The null hypothesis of this study was related with the general perception toward organic food consumption between Serbian and Croatian consumers.

(H0): Consumers in Croatia are more interested in organic food consumers than consumers in Serbia.

The reason for setting up this hypothesis can be found in results of Willer and Lernound studies (Willer, Lernound 2014, 2015, 2017) research that reveals the significant difference between organic market value between these two markets. Additionally, previous researches show that there is certain level of distrust and misunderstanding among organic food concept. Consumers tent to make no differences between organically grown and traditionally grown food or "healthy" food. Hence, the aim of this research is to examine the importance of media on consumer's attitude towards organic concept and to prove the validity of the hypotheses H1.

(H1): Media has significant impact on consumers attitudes towards organic food consumption.

Finally, the profile of the consumers is essential for understanding any marketing phenomena. Previous research that examined the attitude of men and women toward organic foods showed that women have a more favorable relationship (which is related to their way of life) to buying and consuming organic foods compared to men, while men tend to pay a higher price for organic food in comparison with women (Shafie, Rennie, 2009) Therefore, this research will define the profile of Serbian and Croatian organic food consumer and examine the validity of hypothesis $(\mathrm{H} 2)$.

(H2): Woman tends to consume more organic food than men.

\section{Research Methods}

This study used the quantitative methods of research, which was conducted through a questionnaire in which the first part of the issues was related to socio-demographic information about the respondent, while in the second part of research a group of dependent variables was operationalized through the questions with closed answers and statements - Likert assessment scale. The examinees were evaluated to what extent they agree with the claims 
regarding attitudes towards organic food. The research in Serbia involved 260 respondents, of which 124 were male (47.7\%) and 136 were female $(52.3 \%)$ female. The same number of respondents (260) also participated in the research in Croatia, with 93 respondents $(35.8 \%)$ of male and 167 respondents $(64.2 \%)$ of women.

For data analysis, this research used: a descriptive analysis (percentages, arithmetic mean), the chi-square test, t-test, ANOVA, multiple linear regression and Pearson correlation coefficient. The level of significance was set at $\mathrm{p}<0.05$, and all data were processed in SPSS.

\section{Research Results}

The results shows that greatest number of respondents in Serbia (36.9\%) said that they do not relay on organic food products in their regular food consumption while the respondents from Croatian sample expressing different views. Better part of the surveyed respondents (44.2\%) said that they relay on organic food products in their nutrition. Similarly t-test showed that the subjects are different in respect to the use of organic feed in their nutrition $\mathrm{t}(518)=2.08$, $\mathrm{p}$ $<0.05$, the results show that respondents of Croatian (3.14) consume organic food more than the respondents from Serbia (2.94). These results were expected and they are consistent with the previous similar studies conducted by Willer and Lernoud in 2014 and 2016. Hence it can be concluded that these result confirmed the null hypothesis $\mathrm{H} 0$ according to consumers in Croatia consume more organic product that consumers in Serbia.

However, greater importance for this work represents the results that tell us how consumers are looking for information about organic food. The research observed the influence of media regarding decision-making process. Similarly the great importance is the understanding of the level of trust that consumers have towards a particular source of information. This kind of information will enable marketing professionals to deliver information on organic food more successfully and thus influence the increase in its consumption.

Research result shows that more than half of Serbian respondents (58.4\%) do not actively look for information on new organic products. Additionally, 58.5\% of respondents believe that information from the media have no influence on their decision to purchase organic food, while $13.8 \%$ believe that the requested information have an impact on their decision. Moreover, in the case of testing the level of trust the research showed high level of mistrust towards media and advertising as a source of information. According to research results $57 \%$ of Serbian respondents do not trust the information from the media, while $63 \%$ od examine do not believe advertising on organic food.

Although the level of consumption of organic food in Croatia is significant, Croatian consumers do not search for information about new organic products suggestively. Similar to the results from the Serbian sample, almost half of the respondents do not actively search for information about organic products (45.8\%). On the other hand, more respondents from the Croatian sample believes that media have an impact on the decision-making process (29.6\%), while the level of mistrust in the media and a advertising as a source of information is also significant, $45,4 \%$ and $49,6 \%$ respectively. 
Using T-Test the research showed interesting result regarding the organic food information search. The T-Test results show that there are significant differences among the respondents in the Serbian sample when it comes to actively seeking information on new organic products. The results showed that subjects older than 65 years (2.75) search more actively information than other groups of respondents, while the respondents younger than 20 years showed low level of interest for new information. (2.00). Even though the older consumers seek for the information about organic food the most, they do not represent prime target audience. This result can be affected with fact that respondent over 65 are retired and they have more free time. The difference was also found in the Croatian sample and the results show that respondents aged between 41 and 50 (3.08) are more active than other groups, The respondents with the lowest interest for the new information are older than 65 (1.50).

When we look at average values of answers on the scale examined the ratio of respondents towards organic food, the results show that respondents from both samples agree with the statement "I believe advertising on organic food" and "I believe the information from the media about organic food" at least.

Table 3 and 4. values from both samples.

\section{I believe in Organic food advertising}

I believe in information regarding organic food getting from media

Information from media do make influence on my decision making process

I am looking for new information about organic food actively

I like to talk about organic food benefit

I use organic food in my daily nutrition

I would like to produce organic food as entrepreneur

I would like to produce organic food for my own purpose

I support tax-free policy for the organic food advertising and campaign

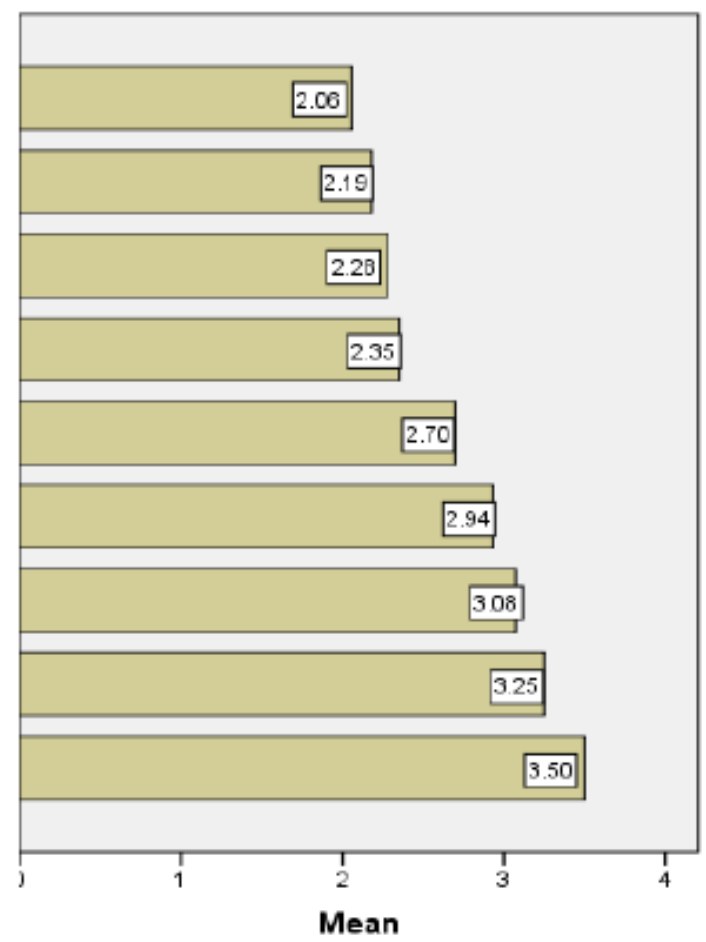


I believe in Organic food advertising

I believe in information regarding organic food getting from media

Information from media do make influence on my decision making process

I am looking for new information about organic food actively

I like to talk about organic food benefit

I use organic food in my daily nutrition

I would like to produce organic food as entrepreneur

I would like to produce organic food for my own purpose

I support tax-free policy for the organic food advertising and campaign

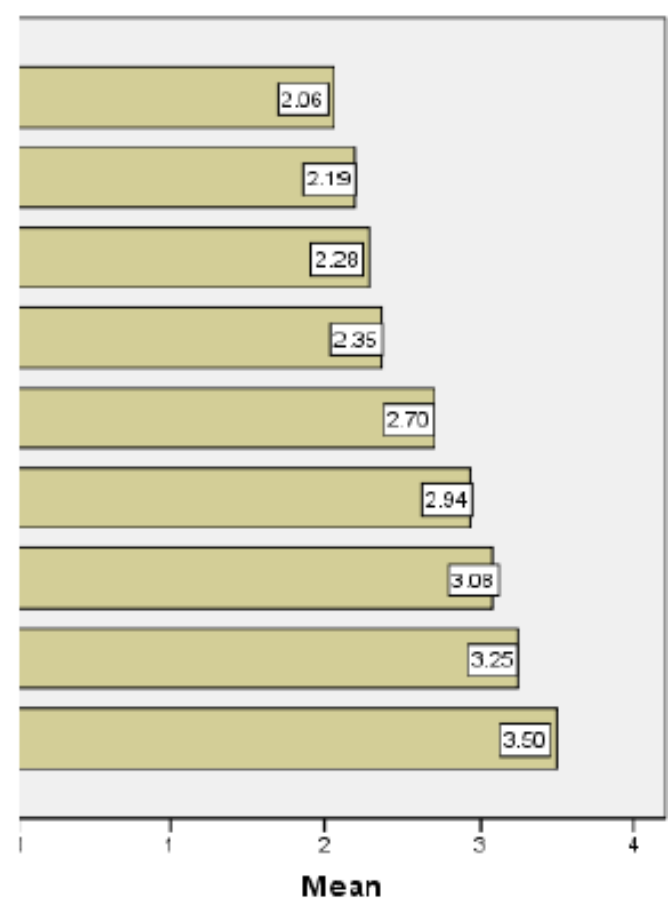

Mean

Source: Authors research

Research has shown that consumers in both sample, Serbian and Croatian, as a source of information mostly used chatting with friends and relatives $49.2 \%$ and $46.5 \%$ respectively. Examinee in both samples listed Internet as the second most favorite source of information with $21.5 \%$ and $31.5 \%$ respectively. Although the results showed a significant degree of distrust in the media, even $10.8 \%$ of respondents from Serbia point out media as a main source of information. On the other hand, this percentage is much lower in the Croatian sample (4.2\%.) An interesting fact is that there is not significant confidence in the conversation with the seller in both samples. These results indicate that there is a high degree of independence and self-awareness during decisions making process about buying organic food. Indeed, the results of Chi-square test showed that most educated respondents $(56.3 \%)$ point out friends and relatives as most usually source od information while the $42.6 \%$ respondents has at least a high school education. Television, radio and the press as a source of information is used by respondents with college or university education (27.8\%), while the internet to a higher percentage than other used subjects who have completed master's, master's or doctoral studies $(31.3 \%)$. Conversation with the seller used only respondents with college or university education (5.6\%). The aforementioned Chi-square test results are relating to the sample from Serbia. Chi-square results from the Croatian sample showed no significant differences. Research results show that the most educated respondents (3.07) are more willing to talk about the benefits of this type of diet than the other categories of respondents. 
Furthermore, research result showed differences in the relation to gender. Men employ chatting with friends and relatives as a source of information more than woman $(61.3 \%)$. Additionally, $12.9 \%$ of male respondents listed television, radio and the press as a source of information compared to $8.8 \%$ of female respondents. On the other hand, women increasingly use the Internet $23.5 \%$ compared to $19.4 \%$ of male respondents. Chatting with sellers, according to the results is reserved for women only, and it does not make any man.

Based on the analysis of the above results, it can be concluded that the research did not prove the existence of hypothesis H1. In other words, research showed that media does not have any significant influence on the decision-making process on the organic food purchase among Serbian and Croatian consumers.

The research has also shown that there are differences between consumer attitudes towards organic food production for both their own needs and for the needs of starting their own business. Almost $65 \%$ of the respondents from Croatia would deal with the production of organic foods, while about $53 \%$ of the respondents would start their own business with the production of organic foods. These percentages are somewhat smaller in Serbia, where about $47 \%$ of respondents would be engaged in the production of organic food for their own needs, while $30 \%$ of respondents would consider organic food production as entrepreneurship. Additionally, research identified significant differences between socio-demographic factors between respondents in Serbia. Respondents between the ages of 51 and 65 (3.75) were more likely to deal with the abovementioned production with the aim of starting their own business. On the other hand, retirees and the unemployed respondents between the ages of 41 and 50, to a greater extent than other groups, would deal with the mentioned production for their own needs. There was no significant difference regarding socio-demographic factors in the Croatian sample.

In order to examine the hypothesis $\mathrm{H} 2$ the study used the T-Test. The T-test examined whether there was a difference between respondents of different sexes (in Serbian and Croatian samples) in responses to dependent variables in which the ratio of respondents to organic foods was assessed. Following generally accepted opinion that women are more aware of their appearance and therefore about their health, the starting point was that women consume more organic food than men. Unpredictably, T-test in Serbain sample shows that respondents differ in the use of organic food in their own nutrition in favor of man (results show that men consume organic food (3.13) more than women (2.76)), The differences between the respondents in the Serbian sample were also found in the influence of information from the media on the decision of the respondents to purchase organic foods. The results show that the mentioned information has a lesser impact on women $(2,15)$ than on men $(2.43)$. Furthermore, the test showed that women (2.50) are less likely to talk about the benefits of organic food compering to man (2.93).

In the Croatian sample, the T-test showed that the respondents differ only in agreeing with the claim "I believe in media information on organic foods" $(258)=2.13, p<0.05$, 
and the results show that women (2.50) less than men (2.77) believe this information. In other variables there were no statistically significant differences between subjects of different sexes.

At the end of the analysis of research result it can be concluded that research did not prove the hypothesis H2 either. The primary Serbian organic food consumer is mid age or older well-educated family men who seek the information regarding organic food chatting with his friends. The Croatian research did not found any significant differences among sexes. However, typical organic food consumer is between 41 and 50 years old who uses conversation with its friends as a basic means of information.

\section{Conclusion}

The presented research was intended to examine whether there are some differences between Serbian and Croatian consumers attitudes when it comes to organic food consumption. Three hypotheses were laid out as starting premise, from which the research proved only null hypothesis $\mathrm{H} 0$ that consumers from Croatia have a more positive attitude to organic food conjugation than consumers in Serbia. The other two hypotheses concerning the importance of the media to the decision-making process as well as defining the profile of organic food consumers have not been proven. When it comes to the importance of the media, the research showed an extremely high degree of non-confidence in the media in both samples. Also, as the most common means of informing about new products and benefits of organic food, the respondents of both markets cited conversation with friends and relatives. When it comes to differences between respondents regarding their demographic characteristics, the results show that there are no statistically significant differences in the sample in the Croatian sample. On the other hand, the results in Serbia show that there are statistically significant differences between the respondents and that well educated employed men, in the fifth decade of life, with higher personal income and five member household are most frequently informed about organic food through interviews with friends, colleagues, relatives and the like.

Such results are important for marketing experts because they point to the importance of the point of sale when it comes to informing about organic products. Indeed, in the literature review, we have seen that previous research shows a certain degree of incomprehension of the concept of organic food and a situation in which consumers identify organic foods with healthy foods.

T test and Anova showed that subjects in both samples could differ significantly in terms of their relationship toward organic food. The results in Serbia show interesting fact that men have more positive attitude towards organic food than women. Moreover they consume more organic food products than women in their regular nutrition. When it comes to the decision making process, information from the media has a greater impact on them, and they are willing to talk about the benefits of organic food to grater extent. In the Croatian sample, the T-test showed that the difference between the respondents 
is only in the claim "I believe in information from the media on organic food", and the results showed that women less than men believe this information.

These results can also be significant for marketing professionals because most of the communication is about healthy nutrition is directed at women. After this analysis, it can be concluded that communication has to be focus on the men as well.

When it comes to differences in respondents from the spice and Croatian samples, the research showed that respondents differ in terms of the use of organic food in their own diet, and that respondents from Croatia rely on organic food products more than the respondents from Serbia. The results also show that there are differences between the respondents regarding the active search for information on new organic products and that respondents in Serbia, to a lesser extent than the respondents in Croatia, are actively informed about the mentioned.

Significant differences between the respondents are also obtained when it comes to the influence of information from the media on the decision of the respondents on the purchase of organic foods, and the results show that the information to a lesser extent influences respondents in Serbia. Similarly, the research showed that level of trust towards advertising is lower among Serbian consumers. In other variables there were no statistically significant differences between the respondents from the Serbian and Croatian samples.

Table 5. Interconnectedness of dependent variables on the Serbian sample

\begin{tabular}{|c|c|c|c|c|c|c|c|c|c|}
\hline & 1 & 2 & 3 & 4 & 5 & 6 & 7 & 8 & 9 \\
\hline 1 & 1 & $.650^{* *}$ & $.475^{* *}$ & $.422^{* *}$ & $.254^{* *}$ & $.691^{* *}$ & $.326^{* *}$ & $.377^{* *}$ & $.396^{* *}$ \\
\hline 2 & & 1 & $.550^{* *}$ & $.383^{* *}$ & $.265^{* *}$ & $.708^{* *}$ & $.352^{* *}$ & $.447^{* *}$ & $.522^{* *}$ \\
\hline 3 & & & 1 & $.750^{* *}$ & $.565^{* *}$ & $.606^{* *}$ & $.350^{* *}$ & $.329^{* *}$ & $.366^{* *}$ \\
\hline 4 & & & & 1 & $.838^{* *}$ & $.551^{* *}$ & .121 & $.161^{*}$ & $.244^{* *}$ \\
\hline 5 & & & & & 1 & $.504^{* *}$ & .086 & .093 & $.284^{* *}$ \\
\hline 6 & & & & & & 1 & $.424^{* *}$ & $.470^{* *}$ & $.585^{* *}$ \\
\hline 7 & & & & & & & 1 & $.225^{* *}$ & $.292^{* *}$ \\
\hline 8 & & & & & & & & 1 & $.780^{* *}$ \\
\hline 9 & & & & & & & & & 1 \\
\hline
\end{tabular}

Source: Authors research

$* \mathrm{p}<0,05$

$* * \mathrm{p}<0,01$

Table 6: Interconnectedness of dependent variables on the Croatian sample

\begin{tabular}{|c|c|c|c|c|c|c|c|c|c|}
\hline & 1 & 2 & 3 & 4 & 5 & 6 & 7 & 8 & 9 \\
\hline 1 & 1 & $.685 * *$ & $.461 * *$ & $.353^{* *}$ & $.334 * *$ & $.606 * *$ & $.326 * *$ & $.487 * *$ & $.322 * *$ \\
\hline 2 & & 1 & $.467 * *$ & $.338^{* *}$ & $.344 * *$ & $.664 * *$ & $.284 * *$ & $.395 * *$ & $.351 * *$ \\
\hline 3 & & & 1 & $.669 * *$ & $.611 * *$ & $.497 * *$ & $.255^{* *}$ & $.256^{* *}$ & $.328 * *$ \\
\hline 4 & & & & 1 & $.803 * *$ & $.371 * *$ & $.199 * *$ & $.167 * *$ & $.273 * *$ \\
\hline 5 & & & & & 1 & $.419 * *$ & $.222 * *$ & $.232 * *$ & $.306 * *$ \\
\hline
\end{tabular}




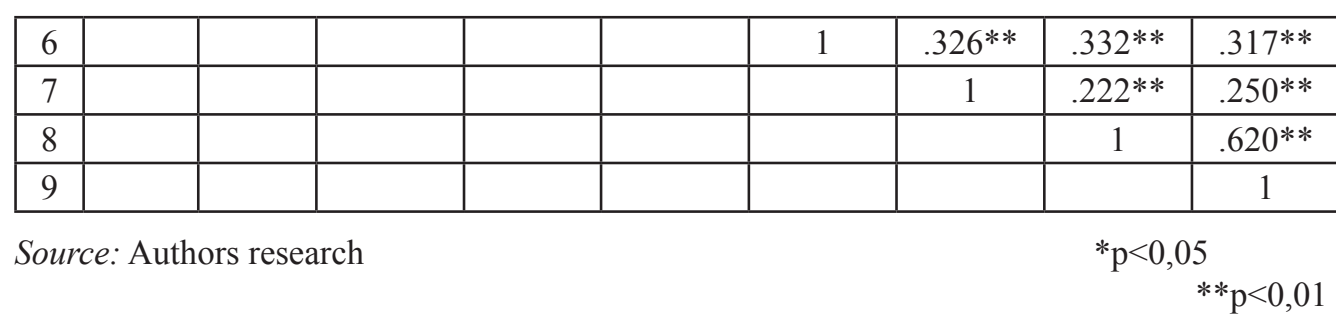

At the end of the paper we can conclude that the biggest difference between consumers in Serbia and Croatia is in the level of trust in the media and organic food advertisements. Based on these results, it can be concluded that the media have a certain degree of influence on consumers in Croatia and that marketing experts can rely on the media in order to affect consumers. On the other hand, consumers in Serbia have very little confidence in advertising and the media in general, why the marketing experts should put emphasis on the point of sale and clear brand communication at the point of sale as well as on the various Internet trough communication (sites, blogs, social networks, etc.). The authors suggest that marketers from both countries should use the study findings to develop specific marketing strategies for positioning, communication, pricing and distribution of organic food brands and products. The study is acknowledged as exploratory and a useful foundation for further research that should be concluded to find broader dependences and specifics.

\section{References}

1. Aerset B., Beckmann S., Bigne E., Beveridge M., Bjorndal T., Bunting J., McDonagh P., Mariojouls C., Muir J., Prothero A., Reisch L., Smith A., Tveteras R., Young J. (2004): The European consumers understanding and perceptions of the "organic" food regime The case of aquaculture, British Food Journal, Vol. 106, No. 2, pp. 93 105, Emerald Publishing Limited, Great Britain

2. Aryal, P., Chaudhary, P., Pandit, S., Sharma, G. (2009): Consumers' willingness to pay for organic products: a case from Kathmandu valley, Journal of Agriculture and Environment, Vol. 10, pp. 15-26, Government of Nepal, Ministry of Agricultural Development, Food Security and Environmental Division, Kathmandu, Nepal, available at: http://www.nepjol.info/index.php/AEJ/issue/view/163

3. Brčić-Stipčević, V., Petljak, K., Guszak, I. (2011): Empirical research of attitudes towards organic food among Croatian consumers, Entrepreneurship and Macroeconomic Management: Refl ections on the World in Turmoil', March 24-

4. Vol. 2, 2011, pp. 1376-1405, Pula, Croatia

5. Brčić-Stipčević (2011): Research in organc food purchase in Croatia, Tržište, Vol. XXIII, No. 2, pp. 189-207, Zagreb, Croatia, available at: https://www.google.rs/url?s $\mathrm{a}=\mathrm{t} \& \mathrm{rct}=\mathrm{j} \& \mathrm{q}=\&$ esrc $=\mathrm{s} \&$ source $=$ web $\& \mathrm{~cd}=3 \& \mathrm{cad}=\mathrm{rja} \&$ uact $=8 \& \mathrm{ved}=0$ ahUKEwitoO LDxPnUAhXkDZoKHbkRAQ4QFggyMAI\&url=http $\% 3 \mathrm{~A} \% 2 \mathrm{~F} \% 2 \mathrm{Fhrcak} . \mathrm{srce} . \mathrm{hr} \%$ 2Ffile\%2F117265\&usg=AFQjCNExyt0XWAqxwxoyCKaLzcvpvUi-VA

6. Cooley, R. et al (Eds.) (2012): New England Tree Fruit Management Guide, Cornell 
University, Ithaca., USA, available at: https://ag.umass.edu/fruit/2012-new-englandtree-fruit-management-guide

7. Farah Ayuni Shafie, Denise Renni, (2009): Consumer Perceptions towards Organic Food, 14-15 November 2009, Procedia - Social and Behavioral Sciences, pp. 360-367, Universiti Teknologi MARA, Selangor, Malaysia, available at: http://ac.els-cdn.com/S1877042812031308/1-s2.0-S1877042812031308-main. pdf? tid=3d200698-630d-11e7-b53d-00000aacb35f\&acdnat=1499429597 da60f210c4f21da3d7b629c0a54eec40

8. Golijanin J.(2016):Motives affecting purchasingorganicfoodproducts, Agroeconomic, Vol. 45. No. 72, pp. 73-81, Poljoprivredni fakultet Univerziteta u Novom Sadu, Novi Sad, Serbia, available at: http://agroekonomika.rs/index.php/2-uncategorised/8agroekonomika-br-72

9. Gifford, K., Bernard, J., (2010): The effect of information on consumers' willingness to pay for natural and organic chicken, International Journal of Consumer Studies, Vol. 34, No. 6, pp. 619-626, John Wiley \& Sons Ltd, New York, USA, available at: http:// onlinelibrary.wiley.com/doi/10.1111/j.1470-6431.2010.00870.x/pdf

10. Heinze, K., (2016): European organic market grew to more than 26 billion euros in 2014, Organic-Market.Info, available at: http://organic-market.info/news-in-briefand-reports-article/european-organic-market-grew-to-more-than-26-billion-eurosin-2014.html

11. Jensen, D., Denver, S., Zanoli, R. (2011): Actual and potential development of consumer demand on the organic food market in Europe, Vol. 58, No. 3, pp. 79-84, NJAS-Wageningen Journal of Life Sciences, Elsevier, Amsterdam, Holland

12. Ilić I., (2016): Analysis of consumption of organic products in Nišava district, Ekomonika, Vol. 62, No. 2., pp. 167-178, Društvo ekonomista Niš, Niš, Serbia, available at: http://www.ekonomika.org.rs/sr/PDF/ekonomika/2016/Ekonomika-2016-2.pdf

13. Kalentić, M., Stefanović, E., Simić I., März, U. (2015): Organska poljoprivreda u Srbiji 2014, Nacionalna asocijacija za organsku proizvodnju Serbia Organica, Belgrade, Serbia,availableat:http://www.kombeg.org.rs/Slike/CeTranIRazvojTehnologija/2015/ jun/Organska $\% 20$ poljoprivreda $\% 20 \mathrm{u} \% 20$ Srbiji $\% 202014$.pdf

14. Kranjac , M., Vapa-Tankosić, J., Knežević, M. (2017): Profile of Organic Food Consumers, Economics of Agriculture, Year64,No.2,pp. 497-514, NDAEB, Beograd, Serbia, available at: http://bsaae.bg.ac.rs/images/Ekonomika\%20kompletna/2017/ EP\%202\%202017\%20lq.pdf

15. Lockie, S., Halpin, D., Gordon, R. (2006): Understanding the market for organic food. In: Kristiansen, P., Taji, A., Reganold, J., editors. Organic Agriculture - A Global Perspective. $1^{\text {st }}$ edition, pp. 245-259, Cabi Publishing, Wallingford, Great Britain

16. March, U., Kalentić, M., Stefanović, E., Simić, I. (2013): Organska poljoprivreda

17. u Srbiji 2013, Nacionalna asocijacija za organsku proizvodnju Serbia Organica, Beograd, Serbia, available at: http://www.serbiaorganica.info/wp-content/ 
uploads/2013/01/OPS FINAL srb.pdf

18. Mitić, S., Gligorijević, M. (2012): Globalni izazovi i perspective marketinga proizvoda zdrave hrane, Marketing, Vol. 43, No. 3, pp. 205-218, SeMA - Srpsko udruženje za Marketing Ekonomski fakultet u Beogradu, Beograd, Serbia, available at: http:// www.sema.rs/repository/download/marketing-vol-43-no-3.pdf

19. Mirecki, N., Wehinger, T \& Jaklič, M. (2011): Priručnik za organsku proizvodnju, Biotehnički fakultet Podgorica, Podgorica, Montenegro

20. Roitner-Schobesberger, B. et al, (2008): Consumer perceptions of organic foods in Bangkok, Thailand, Food Policy, Vol. 33, No. 2, pp. 112-121, Elsevier, Amsterdam, Holland, available at: https://www.researchgate.net/publication/4793648 Consumer Perceptions_of_Organic Foods in Bangkok Thailand

21. Simić, I. (2016): Organic Agriculture in Serbia at Glance, National Association Serbia Organica, Beograd, Serbia, available at: http://www.tehnologijahrane.com/wpcontent/uploads/2016/11/Organic-Agriculture-in-Serbia-At-a-glance-2017.pdf

22. Sylwia Żakowska Biemans, (2011): Polish consumer food choices and beliefs about organic food, Vol. 113, No. 1, pp.122-137, Emerald Publishing Limited, Great Britain

23. Renko, S., Bošnjak, K., (2009): Aktualno stanje i perspektive budućeg razvoja tržišta ekološke hrane u Hrvatskoj, Ekonomski pregled, Vol. 60, No. 7-8, pp. 369-375, Hrvatsko društvo ekonomista, Zagreb, Croatia, available at: $\underline{\text { http://hrcak.srce.hr/40483 }}$

24. Vehapi. S. (2015): Istraživanje motiva potrošača koji utiču na kupovinu organske hrane u Srbiji, Ekonomske teme, Vol. 53, No.1, pp. 105-12, Centar za izdavačku delatnost Ekonomskog fakulteta u Nišu, Niš, Serbia, available at: http://www.economic-themes. com/pdf/et20151 07.pdf

25. Vehapi, S., Dolićanin, E. (2016): Agroeconomic, Consumers Behavior on Organic Food: Evidence from the Republic of Serbia, NDAEB, Year 63, No. 3, pp. 871891, Beograd, Serbia, available at: http://bsaae.bg.ac.rs/images/Ekonomika\%20 kompletna/2016/EP\%203\%202016lq.pdf

26. Vlahović, B. Sojić, S. (2016): Istraživanje stavova potrošača o organskim poljoprivredno-pregrambenim proizvodima i njihovim brendovima, Agroekonomika, Vol. 45, No. 75, pp. 33-46, Poljoprivredni fakultet Univerzitet u Novom Sadu, Novi Sad, Serbia, available at: http://agroekonomika.rs/index.php/2-uncategorised/8agroekonomika-br-72

27. Vlahović, B., Puškarić, A., Jeločnik, M., (2011): Consumer attitude to Organic Food Consumption in Serbia, Vol. 18, No. 1, pp. 45-52, Petroleum Gas University of Ploiesti Bulletin, Ploiesti, Romania, available at: http://www.upg-bulletin-se.ro/ archive/2011-1/6.\%20Vlahovic Puskaric Jelocnik.pdf

28. Willer, H., Lernoud, J., Kikher, L., (Eds.) (2013): The World of Organic Agriculture: Statistics and Emerging Trends 2013, Research Institute of Organic Agriculture (FiBL), Frick, and International Federation of Organic Agriculture Movements (IFOAM), Bonn, Germany, available at: http://orgprints.org/26322/1/1606-organic- 
world-2013.pdf

29. Willer, H., Lernoud, J. (Eds.) (2014): The World of Organic Agriculture: Statistics and Emerging Trends 2014, Research Institute of Organic Agriculture (FiBL), Frick, and International Federation of Organic Agriculture Movements (IFOAM), Bonn, Germany, available at: http://orgprints.org/25172/1/willer-lernoud-2014-world-oforganic.pdf

30. Willer, H., Lernoud, J. (Eds.) (2015): The World of Organic Agriculture: Statistics and Emerging Trends 2015, Research Institute of Organic Agriculture (FiBL), Frick, and International Federation of Organic Agriculture Movements (IFOAM), Bonn, Germany, available at: http:/www.fibl.org/en/media/media-archive/media-release/ article/growth-continues-global-organic-market-at-72-billion-us-dollars-with-43million-hectares-of-organic.html

31. Willer, H., Lernoud, J. (Eds.) (2017): The World of Organic Agriculture: Statistics and Emerging Trends 2017, Research Institute of Organic Agriculture (FiBL), Frick, and International Federation of Organic Agriculture Movements (IFOAM), Bonn, Germany, available at: http:/www.organic-world.net/yearbook/yearbook-2017/key$\underline{\text { data.html }}$ 


\title{
STAVOVI POTROŠAČA O ORGANSKOJ HRANI U SRBIJI I HRVATSKOJ: UPOREDNA ANALIZA
}

\author{
Nenad Peričc, Andrijana Vasić Nikčevič ${ }^{5}$, Nenad Vujićc
}

\begin{abstract}
Rezime
Cilj rada je istraživanje povezanosti socio-demografske varijable i stavova ispitanika iz Srbije i Hrvatske prema organskoj hrani. Potrošači širom sveta imaju pozitivan stav prema organskoj hrani bez posebnih razlika između različitih socio-demografskih varijabli. Međutim, nivo potrošnje organske hrane je nizak-organska poljoprivreda koja pokriva 1\% poljoprivrednog zemljišta. Visoka cena i niska primanja ispitanika predstavljaju osnovne ograničavajuće faktore. Ekonomski faktor je posebno važan za tržišta Srbije i Hrvatske. Takođe, nedostatak informacija i poverenja u organsku proizvodnju i organske sertifikate predstavljaju deo odluke potrošača o kupovini. Prema tome, proizvodima organskih proizvoda potrebna su marketinške aktivnosti za izgradnju prepoznatljivog brenda i razvoj poverenja među potrošačima. Takođe, potrošači su pokazali visok stepen samosvesti u donošenju odluka o kupovini organskih proizvoda, što čini komunikaciju brendom na prodajnom mestu veoma važnom.
\end{abstract}

Key words: konzumiranje organske hrane, stavovi potrošača, proces donošenja odluka.

4 Vanredni profesor, dr Nenad Perić, Metropolitan Univerzitet, Ulica Tadeuša Košćuška br. 63, 11000 Beograd, Srbija, Telefon: +381 112030 885, E-mail: nenad.peric@metropolitan.ac.rs

5 Andrijana Vasić-Nikčević M.Sc., asistent, Metropolitan Univerzitet, Ulica Tadeuša Košćuška br. 63, 11000 Beograd, Srbija, Telefon: +381 112030 885, E-mail:andrijana.vasic@metropolitan.ac.rs

6 Dr Nenad Vujić, viši naučni saradnik, Ekonomski institut, Ulica Kralja Milana br. 16, Beograd, Srbija, Telefon: +381 113613 417, E-mail: nenadvujicvuja@open.telekom.rs 